\title{
METAFORA PADA DESAIN KAOS PRODUKSI KAPUYUAK DAN KONCO CLOTHING
}

\section{METAPHOR ON T-SHIRT DESIGN PRODUCED BY KAPUYUAK AND KONCO CLOTHING}

\author{
Chesil Rulianty, Lindawati, Bahren, Herry Nur Hidayat \\ Fakultas Ilmu Budaya Universitas Andalas
}

\begin{abstract}
ABSTRAK
This article describes the use of metaphoric words of T-shirt design produced by the Kapuyuak and Konco Clothing stores. T-shirts in both stores contain many metaphors about the daily life of Minangkabau people. This study discusses metaphorical forms and functions in the product's design of those two shops. The theory used is the theory of the metaphor form proposed by Stephen Ullman and the theory of functions by Geoffrey Leech. The results show metaphorical forms in the T-shirts design produced by the Kapuyuak and Konco Clothing stores, which are 6 anthropomorphic metaphors, 4 animal metaphors, 7 metaphors from concrete to abstract, and 3 synaesthetic metaphors. Whereas, the functions found are 4 informational functions, 4 expressive functions, 1 directive function, 1 fatigue function, and 10 aesthetic functions.
\end{abstract}

Keywords: metaphor, shirt design, metaphorical form, metaphorical function

\section{PENGANTAR}

Kaos oblong atau disebut juga sebagai $T$-shirt adalah jenis pakaian yang menutupi sebagian lengan, seluruh dada, bahu, dan perut. Kaos oblong biasanya tidak memiliki kancing, kerah, ataupun saku. Pada umumnya, kaos oblong berlengan pendek (melewati bahu hingga siku) dan berleher bundar. Bahan yang umum digunakan untuk membuat kaos oblong adalah katun atau poliester (atau gabungan keduanya).

Mode kaos oblong meliputi mode untuk wanita dan pria, juga dapat dipakai oleh semua golongan usia, termasuk bayi, remaja, ataupun orang dewasa. Sekarang kaos oblong tidak lagi hanya digunakan sebagai pakaian dalam tetapi juga sebagai pakaian sehari-hari. Desain yang dipakai pada baju kaos pada saat ini juga mengikuti perkembangan zaman, dari desain yang rumit hingga sederhana. Salah satu desain adalah dengan menerapkan gambar maupun kalimat-kalimat. Pada artikel ini, penulis mendeskripsikan desain pada baju kaos dari dua toko yaitu toko Kapuyuak dan toko Konco Clothing. Adapun desain yang menjadi fokus pada penelitian ini adalah tulisan yang terdapat pada baju kaos yang mereka produksi dan mengandung metafora.

Metafora merupakan bahasa kiasan yang menarik untuk dikaji. Secara sederhana, metafora adalah analogi atau perbandingan sesuatu yang memiliki kemiripan dengan sesuatu yang lainnya. Metafora termasuk ke dalam bahasa kias. Metafora merupakan bahasa kiasan yang menyebutkan sebuah citra atau pembanding. Meskipun sesungguhnya berbeda pembanding dijadikan senilai dengan objek yang dibandingkan. Keterkaitan antara keduanya diciptakan oleh pembaca berdasarkan konteks yang ada (Luxemburg, Bal, \& Westseijn, 1989). Metafora adalah kesamaan esensial yang disampaikan secara visual melalui kata-kata dan gambar, atau melalui 


\section{Jurnal Elektronik WACANA ETNIK - Vol 6 No 2 Oktober 2017, (56 - 66) \\ p ISSN 2089-8746, e ISSN 2302-7142}

cara akustik atau sentuhan (Marcus, 1998). Menurut Kridalaksana (Kridalaksana, 2008), metafora merupakan pemakaian kata atau ungkapan lain untuk objek atau konsep lain berdasarkan kias atau persamaan.

Menurut Anwar (Anwar, 1992), cara berpikir orang Minangkabau bersifat metaforis, yakni lebih pada berbelit-belit dalam berbicara dengan mitra tuturnya. Orang Minangkabau cenderung tidak terus terang dalam mengungkapkan sesuatu yang tersimpan dalam pikirannya. Dapat dilihat bahwa penggunaan metafora tidak hanya terbatas pada kesastraan. Dalam dunia industri, hubungan antar perusahaan kadang menggunakan metafora (Schwen \& Hara, 2003).

Bagi desainer, metafora adalah bidang ilmu yang bisa digunakan untuk berproduksi. metafora bisa menjadi alat yang ampuh untuk desainer, baik dalam proses mendesain dan dalam produk itu sendiri. Metafora dapat membantu mendefinisikan kembali masalah desain dan membantu menyelesaikannya. Bisa digunakan sebagai alat penelitian, untuk memahami bidang studi baru, atau sebagai sarana untuk menghasilkan ide-ide baru tentang mata pelajaran yang akrab. Ini dapat membantu menjual suatu produk, keduanya kepada pemangku kepentingan internal dan rekan tim serta konsumen. Metafora dapat memberikan isyarat kepada pengguna bagaimana memahami produk: untuk mengarahkan dan personifikasi. Singkatnya, desainer interaksi dapat menggunakan metafora untuk mengubah perilaku (Saffer, 2005).

Demikian yang tampak pada Kapuyuak dan Konco Clothing. Desain yang dipakai oleh kedua toko tersebut banyak berisi kalimat dan gambar yang mengandung metafora pada setiap desainnya. Metafora itu berkaitan dengan kehidupan sehari-hari masyarakat Minangkabau. Metafora yang dipakai oleh kedua toko tersebut dalam produknya ini hanya dimengerti oleh masyarakat Minangkabau saja. Akan tetapi, banyak masyarakat di luar Minangkabau yang tertarik pada hasil produk dari kedua toko tersebut karena hasil sablon yang mereka pakai unik dan menarik.

Dalam dunia desain, metafora tidak hanya digunakan untuk fashion. Metafora desain juga berperan penting dalam pembuatan perangkat lunak (Campbell, 1996; Marcus, 1998; Schwen \& Hara, 2003; Stubblefield, 1998), arsitektur (Casakin, 2012; Johnson, 2006), koreografi (Janesick, 1994), bahkan desain batik (Ekow \& Vincentia, 2013).

\section{KERANGKA PEMIKIRAN DAN METODOLOGI}

Metafora dilihat sebagai "penyimpangan" dan perlu dijelaskan dalam istilah penggunaan bahasa "normal". Memang, metafora pada umumnya dipandang sebagai hal baru, untuk digunakan untuk tujuan retoris tertentu. Metafora, itu dianggap, menghalangi bahasa konvensional dan dunia "literal", yang bisa dipahami sepenuhnya tanpa metafora. Ahli bahasa seperti John R. Seale merasa bahwa metafora hanya dapat dipahami dengan memulainya makna literal, kemudian membandingkannya dengan makna kiasan, menciptakan perpecahan harfiah-kiasan yang ahli bahasa kemudian akan menegur (Saffer, 2005). Pada akhirnya, metafora akan dipahami secara alami dan memungkinkan mengambil benda dan pengalaman konkret dan melemparkannya kembali ke konsep atau hal yang tidak diketahui atau abstrak dan mereka struktur dan berarti.

Aliran tradisional menganggap metafora sebagai perumpamaan yang dihadirkan tanpa menyebutkan dasar perbandingan. Metafora terjadi bila kata yang satu dipakai untuk mengacu kata yang lain. Pemilihan metafora dilakukan berdasarkan kemiripan arti atau kontras. Aristoteles menyatakan bahwa metafora adalah 


\section{Jurnal Elektronik WACANA ETNIK - Vol 6 No 2 Oktober 2017, (56 - 66) \\ p ISSN 2089-8746, e ISSN 2302-7142}

hanya digunakan dalam novel dan sebagai pengajaran alat. Untuk memahami metafora, dia berpendapat, pendengar harus menemukan sesuatu yang umum antara metafora dan subjeknya. Metafora tidak hanya merujuk pada sesuatu, tetapi juga menjelaskan beberapa aspeknya. Ketika seorang pembicara menggunakan metafora, pendengar mempelajari karakteristik subjek yang berbeda metafora.

Metafora adalah sebuah kesamaan antar makna. Metafora sangat bertali-temali dengan jaringan tutur manusia, yakni sebagai faktor utama motivasi, sebagai alat untuk berekspresi, sebagai sumber sinonim dan polisemi, sebagai penyalur emosi yang kuat dan masih banyak peran lainnya. Noble (Noble, Biddle, \& Tempero, 2002) membedakan metafora dengan metonimi dari karakter dasarnya yaitu atribut, sebab, dan efek.

Stephen Ullmann (Ullmann, 2007) mengatakan bentuk metafora terbagi atas empat, yakni metafora antropomorfis, metafora abstrak, metafora seanestetis dan metafora binatang. Metafora antropomorfis adalah metafora yang membandingkan dengan mengasosiasikan unsur-unsur badan manusia dengan alam sekitarnya, atau membandingkan tubuh atau anggota badan manusia dengan indra atau perasaannya. Dalam semua bahasa sebagian besar ekspresi yang mengacu kepada benda-benda yang tak bernyawa dibandingkan dengan cara pengalihan (transfer) dari tubuh dan anggota badan manusia, dari indra dan perasaan manusia. Kecenderungan ini dibuktikan dalam berbagai bahasa dan peradaban, dan terletak pada akarnya ekspresi yang tak terhitung jumlahnya dalam pemakaian. Contoh metafora antropomorfis dalam Bahasa Minangkabau yaitu seperti batapuak sabalah tangan 'bertepuk sebelah tangan', bibia co asam sauleh 'bibir seperti asam seulas'.

Metafora seanestetis merupakan yang umumnya didasarkan pada transfer atau perubahan dari suatu indra ke indra lain. Hubungan seanestetis mempunyai hubungan etimologis. Misalnya dalam bahasa Yunani ada kata baryton (jenis suara laki-laki di antara tenor dan bas adalah jenis suara terbesar) didasarkan pada sebuah kata yang berarti berat (Ullmann, 2007). Salah satu tipe metafora seanestetis berdasarkan pengalihan dari satu indra ke indra yang lain ada pada ungkapan dalam kehidupan sehari-hari. Masyarakat sering mendengar ungkapan "enak didengar" untuk musik walaupun makna enak selalu dikaitkan dengan indra perasa. "sedap dipandang mata" merupakan pengalihan dari indra perasa ke indra penglihatan.

Contoh pada Bahasa Minangkabau pengalihan indra seperti ndak bisa kaki, bia tangan nan bajalan 'tidak bisa kaki, biar tangan yang berjalan' mengibaratkan sesuatu hal yang terjadi sehabis-habisnya cara berpikir akan suatu hal. Artinya tidak ada yang tidak mungkin, asalkan selalu ada usaha untuk mengerjakan. Secara harfiah, tangan tidak bisa digunakan untuk berjalan, melainkan digunakan untuk menulis, makan, mengambil sesuatu dan lain sebagainya.

\section{TEMUAN DAN PEMBAHASAN}

Metafora merupakan sebuah kekuatan kreatif dalam bahasa. Menurut Aristoteles (dalam Ullmann, 2007), "Hal terbesar selama ini adalah menguasai metafora. Metafora sendiri tidak dapat dipisahkan dengan yang lain. Ia merupakan tanda kejeniusan penuturnya”. Faktor dalam keefektifan metafora ditentukan oleh jarak antara suatu yang dibicarakan tenor (makna atau arah umum) dengan bandingannya wahana (Vehicle). Metafora dalam penggunaannya sebagai faktor utama motivasi, sebagai perangkat ekspresi, sebagai sumber sinonim dan polisemi, sebagai seluruh bahasa yang kuat, dan juga sebagai alat mengisi kesenjangan dalam kosa kata. 


\section{Jurnal Elektronik WACANA ETNIK - Vol 6 No 2 Oktober 2017, (56 - 66) \\ p ISSN 2089-8746, e ISSN 2302-7142}

Ditemukan 4 jenis bentuk metafora yang terdapat dalam desain kaos produksi toko Kapuyuak dan Konco Clothing. Keempat jenis metafora tersebut adalah sebagai berikut.

\section{METAFORA ANTROPOMORFIS}

Metafora antropomorfis adalah metafora yang membandingkan sifat maupun sikap manusia dengan cara mengasosiasikan unsur-unsur badan manusia dengan alam sekitarnya, atau membandingkan tubuh serta anggota badan manusia dengan indra atau perasaannya. Hal ini mengalihkan unsur-unsur badan manusia serta mengumpamakannya dengan binatang atau benda tak bernyawa. Setelah mencermati semua data dan mengelompokkannya berdasarkan bentuk, maka ditemukan 5 buah metafora antropomorfis yang membandingkan unsur badan manusia dengan alam sekitarnya.

\section{Hati kareh darah badampuang}

'Hati keras, tetapi tidak berani'

Hati kareh darah badampuang adalah desain baju kaos dari toko Kapuyuak yang diproduksi pada bulan Desember tahun 2015.Konteks dari data ini adalah pemilik toko Kapuyuak menyebutkan bahwa data merupakan sebuah perumpamaan sifat seorang manusia. Data ini dikatakan sebagai metafora antropomorfis karena mencitrakan bagian pada tubuh manusia seperti hati dan darah.

Metafora antropomorfis adalah metafora yang membandingkan dengan mengasosiasikan unsur-unsur badan manusia dengan alam sekitarnya, atau membandingkan tubuh atau anggota badan manusia dengan indra dan perasaannya. Data mengandung makna sifat keras hati seseorang, mempunyai keinginan yang kuat, hasrat yang besar akan sesuatu hal tetapi tidak kuat atau takut untuk menghadapi risiko dari hal yang diinginkannya tersebut.

Pada kasus ini hati dan darah manusia yang terdapat pada perumpamaan di atas menyatakan keadaan psikologi seseorang yang mempunyai semangat juang yang tinggi atau mempunyai hasrat mencapai sesuatu hal tetapi terselip sebuah rasa cemas untuk mencapai hal tersebut. Badampuang dalam kamus Bahasa Minangkabau berarti ada rasa kecut; takut; atau khawatir. Jika dilihat dari konteks, badampuang pada perumpamaan ini dapat diartikan kepada rasa takut yang membuat dia tidak berani melakukan sesuatu hal atau menyatakan sifat tidak berani dan kurang percaya diri.

Anto : den suko jo Rani tu Ndri a

Andri : kecekan lah ka Rani tu langsuang dang

Anto :Ndak! Takuik den.

Andri : dasar. Hati kareh, darah badampuang ang mah!

Anto : Aku suka sama Rani, Ndri

Andri : Bilang saja langsung ke Rani

Anto : Tidak! Aku takut

Andri : dasar. Hati keras, tetapi takut kamu!

Dilihat dari data, sebuah perbincangan menggunakan perumpamaan pada data Hati kareh darah badampuang dengan konteks kehidupan remaja. Jika dikaitkan dengan lingkungan kehidupan remaja pada data tersebut berarti seseorang yang menyukai seorang perempuan tetapi ia takut untuk mengatakannya karena banyak hal yang menjadi pertimbangan untuk tetap memendam dan tidak mengatakan langsung kepada perempuan tersebut. 


\section{Jurnal Elektronik WACANA ETNIK - Vol 6 No 2 Oktober 2017, (56 - 66)}

p ISSN 2089-8746, e ISSN 2302-7142

Ndak amuah dibao ka tangah

Di tapi se lah karam

'Tidak bisa dibawa ke tengah

Di pinggir saja sudah tenggelam'

Data Ndak amuah dibao ka tangah di tapi se lah karammerupakan desain dari baju kaos yang diproduksi oleh Kapuyuak pada bulan juni tahun 2015. Pada data ini merupakan metafora karena telah mengibaratkan seseorang kepada sebuah kapal. Meskipun pada data tidak ada menggunakan kata yang merujuk pada seorang manusia, tetapi konteks yang didapat dari hasil wawancara, pemilik toko Kapuyuak mengatakan data adalah sifat seorang manusia. Perumpamaan ini dikatakan sebagai metafora yaitu karena seseorang manusia yang diibaratkan seperti kapal, secara tertulis dalam perumpamaan ini tidak ada yang menuliskan kapal sebagai objeknya. Tetapi secara isyarat pada perumpamaan ini menyatakan seseorang seperti kapal yang tidak bisa dibawa ke tengah, dipinggir saja sudah tenggelam.

Makna ungkapan tersebut adalah mengibaratkan seseorang dengan sifat yang negatif yaitu tidak bisa untuk diajak bermusyawarah dan berdiskusi untuk menentukan suatu hal. Pada kata Ndak amuah dibao ka tangah adalah menunjukkan seseorang yang tidak bisa dibawa untuk bermusyawarah berdiskusi atau tidak bisa untuk seiya sekata, dan diperjelas dengan kata di tapi se lah karam.

\section{METAFORA BINATANG}

Metafora binatang adalah sifat manusia yang diasosiasikan seperti sifat binatang. Seorang manusia dapat disamakan dengan binatang seperti si babi, si belut, si kerbau, si cacing, si beo dan sebagainya. Terkadang, bendabenda yang tidak bernyawa ada juga yang bertingkah, dan tingkah ini juga dapat dimetaforakan dengan sumber binatang seperti; oto tu mananduak onda dari balakang 'mobil itu menanduk motor dari belakang'.

Hasil pengelompokan data sesuai konteks, maka di dapatilah beberapa metafora binatang pada desain baju kaos produksi toko kapuyuak dan konco clothing. Berikut analisis data yang termasuk ke dalam metafora binatang.

\section{Laki-laki Buayo \\ 'Laki-laki buaya'}

Metafora pada data Laki-laki Buayo yang diproduksi oleh Konco Clothing pada bulan Maret tahun 2015 di atas mengibaratkan laki-laki sebagai buaya dan termasuk ke dalam metafora binatang. Metafora binatang adalah di mana sifat manusia yang diasosiasikan seperti sifat binatang. Secara konteks, data Laki-laki Buayo dibuat karena dilatar belakangi oleh sifat pria yang mengandung makna negatif karena menggemari banyak wanita dan suka mempermainkan hati wanita. Laki-laki yang bila dikatakan seperti buaya telah menjadi sifat negatif yang selalu melekat di pikiran masyarakat. Pemberian julukan buaya untuk lelaki hidung belang rupanya karena buaya dalam arti sesungguhnya adalah pemakan bangkai. Bangkai adalah tubuh yang sudah mati biasanya dipakai untuk binatang, selain bau juga menyimpan bibit penyakit.

Pemberian nama dengan konotasi buruk tertuju pada pria bukan pada wanita, karena dalam hal ini wanita yang jadi korban. Untuk predikat wanita yang tidak baik ada julukan yang lain selain kata buaya. Buaya dalam 


\section{Jurnal Elektronik WACANA ETNIK - Vol 6 No 2 Oktober 2017, (56 - 66) \\ p ISSN 2089-8746, e ISSN 2302-7142}

KBBI adalah binatang berdarah dingin yang merangkak (reptil) bertubuh besar dan berkulit keras, bernafas dengan paru-paru, dan hidup di air. Sementara laki-laki adalah manusia, bukan binatang.

\section{METAFORA KONKRET KE ABSTRAK}

Metafora dari konkret ke abstrak juga berarti mengalihkan ungkapan-ungkapan yang abstrak ke ungkapan yang lebih konkret. Abstrak di sini adalah sesuatu hal yang tidak mungkin. Sering kali pengalihan ungkapan itu masih bersifat transparan tetapi dalam beberapa kasus penelusuran etimologi perlu dipertimbangkan untuk memenuhi metafora tertentu contohnya, secepat kilat 'satu kecepatan yang luar biasa', moncong senjata 'ujung senjata'. Metafora dari konkret ke abstrak yang terdapat dalam desain baju kaos produksi toko kapuyuak dan konco clothing adalah sebagai berikut.

Mamintak sisiak ka limbek

'Meminta sisik pada ikan lele'

Pada data Mamintak sisiak ka limbek produksi Kapuyuak pada bulan September tahun 2015 disebutkan sebagai metafora dari konkret ke abstrak. Konteks dari data ini adalah ketika pemilik toko Kapuyuak banyak melihat orang-orang yang berharap pada sesuatu tanpa mengetahui kapasitas dari yang sesuatu hal tersebut. Lele merupakan ikan air tawar yang badannya licin, bagian mulutnya mempunyai sungut yang panjang, dan lele tidak memiliki sisik. Pada ungkapan ini mengandung makna literal yaitu sebuah permintaan yang tidak mungkin untuk dikabulkan, ini dapat kita lihat pada ungkapan di atas meminta sisik pada lele adalah hal yang tidak mungkin karena lele tidak mempunyai sisik.

Masyarakat Minangkabau biasa mengungkapkan hal ini ketika ada suatu hal yang tidak dapat dilakukan atau diwujudkan. Ungkapan ini hampir serupa dengan ungkapan Minangkabau lainnya yaitu seperti bakandak tanduak ka kudo 'minta tanduk pada kuda'.

Lah mode kuburan cinto uda diak, langang

'Sudah seperti kuburan cinta abang Dik, sepi'

Data lah mode kuburan cinto uda diak, langang yang diproduksi oleh Konco Clothing pada bulan Oktober tahun 2015 menyebutkan yang menyerupai sebuah kuburan adalah perasaan cinta. Cinta adalah perasaan sayang seseorang kepada orang lain, kenyataannya cinta tidak bisa di kubur karena tidak memiliki jasad. Makna literal dari ungkapan data adalah seorang pria yang merasa cintanya seperti sebuah kuburan, kuburan biasanya sepi, tidak ada manusia yang berlalu lalang di sana kecuali jika ada keperluan seperti ziarah dan lain sebagainya. Ia mengibaratkan cintanya seperti kuburan karena sepi, tidak ada yang datang. Konteks pada data adalah tidak lagi memiliki rasa cinta.

\section{METAFORA SEANESTETIK}

Merupakan salah satu tipe metafora berdasarkan pengalihan indra, pengalihan dari satu indra ke indra yang lain. Dari indra bunyi (pendengaran) ke indra penglihatan, dan sebagainya (Ullmann, 2007:269). Metafora seanestetis biasanya muncul dalam puisi maupun prosa. Metafora seanestetis pada desain baju kaos produksi toko Kapuyuak dan Konco Clothing adalah sebagai berikut. 


\section{Jurnal Elektronik WACANA ETNIK - Vol 6 No 2 Oktober 2017, (56 - 66)}

p ISSN 2089-8746, e ISSN 2302-7142

Kaji nan ka indak

'Menonton radio, mendengar koran

al yang tidak mungkin'

Harfiahnya manusia menonton televisi dan membaca koran, tetapi pada ungkapan data Manonton radio, mandanga koran, kaji nan ka indak yang diproduksi oleh Konco Clothing pada bulan Oktober tahun 2015 mengatakan hal yang terbalik. Data termasuk ke dalam metafora seanestetis, metafora seanestetis adalah sebuah metafora berdasarkan pengalihan indra, pengalihan dari satu indra ke indra yang lain.

Pengalihan indra di sini ada pada indra penglihatan dan pendengaran. Ungkapan ini mengatakan manonton radio dan mandanga Koran, hal ini mengandung makna tentang sesuatu yang tidak akan bisa terjadi karena radio hanya bisa di dengar dan koran hanya bisa dibaca.

Hai adiak, nan lamak dipandang mato

'Hai adik, yang enak

dipandang mata'

Data Hai adiak, nan lamak dipandang mato yang diproduksi oleh Konco Clothing pada bulan November tahun 2015 ini termasuk ke dalam metafora seanestetis. Konteks data yaitu sebuah penyampaian perasaan dari seseorang yang disampaikan lewat desain baju kaos tersebut untuk menyapa pembaca desain dari baju kaos yang diproduksi itu sendiri. Lamak dikategorikan pada indra pengecap, biasanya yang dikecap adalah rasa dari makanan dan minuman dengan cara memasukkan ke dalam mulut.

Pada kasus ini, Konco Clothing mengungkapkan lamak 'enak' melihat seorang wanita.Hal ini termasuk ke dalam pengalihan indera yaitu dari indra pengecap dengan indra penglihatan. Data (20) Hai adiak, nan lamak dipandang mato merupakan metafora yang mengandung unsur pembanding antara kecantikan seorang wanita yang diungkapkan dengan kata enak dipandang mata. Makna dari perumpamaan di atas adalah seseorang pria yang menyapa seorang wanita yang cantik. Cantik di sini ada pada perumpamaan lamak di pandang mato 'enak dipandang mata'.

\section{ANALISIS FUNGSI}

Analisis fungsi metafora dalam desain baju kaos produksi toko kapuyuak dan konco clothing ini mencakup analisis fungsi informatif (memakai bahasa untuk menyampaikan informasi kepada orang lain mengenai keadaan-keadaan eksternal atau pokok persoalan), fungsi ekspresif (memakai bahasa untuk mengungkapkan perasaan, keadaan-keadaan internal individu atau penutur/penulis), fungsi direktif(mengarahkan atau mempengaruhi perilaku atau sikap orang lain pendengar/pembaca), fungsi fatik (memelihara hubungan yang baik di dalam kelompok sosial atau sarana komunikasi), dan fungsi estetik (menciptakan efek artistik atau pesan) (Leech, 2003:63-88).

\section{ANALISIS FUNGSI INFORMASIONAL}

Fungsi informatif di sini adalah desain-desain baju kaos yang menyampaikan informasi kepada orang lain baik itu mengenai keadaan eksternal atau yang berhubungan dengan Minangkabau.

Minang Darah den

'Minang darah saya' 


\section{Jurnal Elektronik WACANA ETNIK - Vol 6 No 2 Oktober 2017, (56 - 66) \\ p ISSN 2089-8746, e ISSN 2302-7142}

Informasi ini berupa pemberitahuan bahwa Minangkabau telah menjadi darahnya. Hal ini merupakan ungkapan untuk sebuah kecintaannya kepada Minangkabau yang diungkapkan untuk diketahui oleh khalayak ramai dalam bentuk desain pada sebuah baju kaos.

Data tersebut termasuk ke dalam fungsi informatif karena menyampaikan hal-hal eksternal yang berhubungan dengan Minangkabau. Hal-hal yang berhubungan dengan Minangkabau di sini diperjelas dengan adanya tulisan kata Minangkabau pada desain baju kaos yang di produksi oleh Kapuyuak tersebut. Hubungan eksternal yang terdapat dalam data tersebut adalah ditujukan oleh penulis kepada khalayak ramai dengan maksud memberi tahu bagaimana kondisi internal (yang ada dalam dirinya) kepada eksternal (masyarakat di luar dirinya).

Sobok pembimbing lah mode kuciang takuik jo lidi

Mahasiswa tahun akhia

'Bertemu pembimbing sudah seperti kucing takut dengan lidi

Mahasiswa tahun akhir'

Desain baju Konco Clothing yang diproduksi pada bulan Mei tahun 2015 ini termasuk ke dalam fungsi informatif. Data mengandung sebuah informasi perihal mahasiswa tahun akhir yang takut bertemu dengan dosen pembimbingnya. Mahasiswa tahun akhir identik dengan skripsi yang belum diselesaikan sehingga menunda selesainya perkuliahan. Takut dalam hal ini karena setiap proses pembuatan skripsi dibimbing oleh dosen pembimbing sehingga menimbulkan ketakutan mahasiswa bertemu dengan dosen pembimbingnya di saat tidak adanya kemajuan dalam proses pembuatan skripsi tersebut.

\section{pas jaman gadget wakatu ngumpua; \\ lah mode radio, mangecek surang \\ 'etika zaman gadget waktu ngumpul; \\ Sudah seperti radio, bicara sendiri'}

Data di atas termasuk ke dalam fungsi informatif karena dalam data ini memberitahu tentang keadaan internal ketika sedang berkumpul dengan teman-teman pada zaman modern. Zaman gadget (handphone, laptop, mp3 player) di sini adalah zaman anak-anak muda lebih sering menyibukkan diri dengan barang-barang tersebut, sehingga ketika sedang berkumpul sering kali tidak fokus dengan teman yang sedang berbicara. Hal ini menimbulkan sebuah perasaan kecewa atau marah dari seorang penutur karena tidak adanya respons dari mitra tutur akan apa yang sedang dibicarakannya. Jadi, penutur mengibaratkan dirinya seperti radio yang berbicara sendiri tanpa adanya tanggapan dari pendengar.

Manonton radio, mandanga koran

Kaji nan ka indak

'Menonton radio, mendengar Koran

Tidak masuk akal'

Data produksi dari Konco Clothing yang diproduksi pada bulan Oktober tahun 2015 mempunyai fungsi informatif. Fungsi informasi yang terkandung di dalam ungkapan di atas adalah pemberitahuan tentang sebuah hal yang tidak mungkin untuk dikerjakan seperti menonton radio dan mendengar koran. 


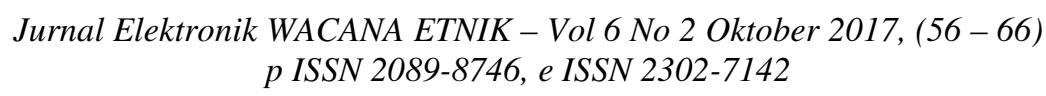

\section{ANALISIS FUNGSI EKSPRESIF}

Fungsi ekspresif, yaitu fungsi yang digunakan untuk mengungkapkan perasaan dan sikap penuturnya. Fungsi ekspresif yang diuraikan dalam penelitian ini adalah desain-desain baju kaos yang memiliki fungsi sebuah pengungkapan perasaan.

Hati kareh, darah badampuang 'hati keras, tapi tidak berani'

Data tersebut merupakan sebuah pengungkapan perasaan yang didesain oleh Kapuyuak pada bulan Desember tahun 2015. Pengungkapan perasaan di sini jelas tertulis pada ungkapan di atas, bahwa perasaan yang terkandung di dalamnya adalah sebuah perasaan ingin mengerjakan sesuatu tetapi takut untuk melaksanakan hal tersebut.

Cinto uda batapuak sabalah tangan diak

'Cinta abang bertepuk sebelah tangan dek'

Data di atas diproduksi oleh Konco Clothing pada bulan Januari tahun 2015 ini termasuk ke dalam fungsi ekspresif karena tergolong pada pengungkapan perasaan. Pengungkapan sebuah perasaan yang terkandung di dalam perumpamaan data ini adalah berupa pemberitahuan akan perasaan seseorang yang tidak berbalas. Hal ini di ungkapkan pada kalimat cinto uda batapuak sabalah tangan, diak. Kalimat tersebut mengindikasikan sebuah perasaan seseorang kepada orang lain.

\section{Baruak dapek pamainan}

'Beruk dapat permainan'

Data di atas merupakan sebuah pengungkapan perasaan atas sifat seseorang yang di asosiasikan sama dengan binatang yaitu beruk. Data di produksi oleh Konco Clothing pada bulan Juni tahun 2015.

lah mode kuburan cinto uda diak, langang

'Sudah seperti kuburan cinta abang dek, sepi'

Desain dari Konco Clothing dalam data yang di produksi pada bulan Oktober tahun 2015 termasuk kedalam fungsi ekspresif. Data ini berisikan pengungkapan sebuah perasaan seseorang yang ingin diberitahukan kepada orang lain. Hal ini menyatakan bahwa orang tersebut memiliki perasaan kecewa karena kisah asmaranya yang kurang beruntung. Kurang beruntung di sini maksudnya adalah seseorang yang belum memiliki pasangan dan mengibaratkan perasaannya yang sepi seperti sebuah kuburan. Berdasarkan analisis di atas, penulis mengelompokkan data memiliki fungsi ekspresif karena berangkat dari sebuah pengungkapan perasaan seseorang kepada orang lain.

\section{ANALISIS FUNGSI DIREKTIF}

Fungsi direktif yaitu fungsi yang digunakan untuk mempengaruhi perilaku atau sikap orang lain, lebih memberikan tekanan pada sisi penerima dan bukan pada sisi penutur. Fungsi direktif ini mempengaruhi perilaku atau sikap orang lain dalam bentuk perintah, permohonan, ajakan, dan larangan.

Ukua bayang sapanjang badan

'ukur bayang sepanjang badan' 


\section{Jurnal Elektronik WACANA ETNIK - Vol 6 No 2 Oktober 2017, (56 - 66) \\ p ISSN 2089-8746, e ISSN 2302-7142}

Data di atas diproduksi oleh Kapuyuak pada bulan Februari tahun 2015. Data ini termasuk ke dalam fungsi direktif karena merupakan sebuah kalimat suruhan atau perintah. Kalimat perintah adalah kalimat yang dibentuk untuk memancing respons yang berupa tindakan (Tarigan, 1995). Responsi yang diharapkan pada data ini adalah berupa sebuah kesadaran dalam diri seseorang yang dituju untuk mengubah sikapnya dari buruk menjadi lebih baik. Setiap keinginan haruslah sesuai dengan kemampuan begitulah arti dari ungkapan tersebut.

\section{ANALISIS FUNGSI FATIK}

Fungsi fatik yaitu fungsi yang digunakan untuk menjaga agar saluran komunikasi tetap terbuka, dan juga digunakan untuk terus menjaga hubungan sosial secara baik. Fungsi fatis juga merupakan (pembina dan pemelihara hubungan antarpenutur) sama dengan orientasi kontak (komunikasi).

Hai adiak, nan lamak dipandang mato

'hai adik, yang enak dipandang mata'

Analisis fungsi fatik yang terdapat pada data di atas yaitu adanya sebuah pengadaan kontak dengan orang yang dituju misalnya orang yang membaca desain tersebut. Pengadaan kontak yang dimaksud adalah sebuah keinginan untuk memulai sesuatu pembicaraan dengan lawan bicara, bisa terjadi setelah yang dituju ditunjukkan desain pada baju kaos tersebut.

\section{PENUTUP}

Kaos pada zaman sekarang merupakan pakaian yang dapat dipakai setiap hari oleh masyarakat. Karena bahannya yang ringan dan sejuk serta simpel untuk dipakai, tak sedikit masyarakat yang ingin membuat baju kaos biasa berubah menjadi unik dengan kreativitasnya. Desain yang digunakan banyak menggunakan bahasa daerah itu sendiri, guna untuk merevitalisasikan bahasa daerah kepada anak muda zaman sekarang. Contohnya banyaknya dibuka tempat sablon baju kaos di daerah-daerah yang mempermudah masyarakat untuk membeli atau sekedar mengoleksi baju kaos dengan desain yang unik dan kreatif. Beberapa di antaranya yang menjadi objek penelitian adalah desain baju kaos yang diproduksi oleh Kapuyuak dan Konco Clothing.

\section{DAFTAR PUSTAKA}

Anwar, K. (1992). Semantik Bahasa Minangkabau. Padang: Yayasan Pengkajian Minangkabau.

Campbell, D. a. (1996). Design in Virtual Environments Using Architectural Metaphor. University of Washington. Retrieved from http://cumincad.scix.net/cgibin/works/Show?_id=b27f\&sort=DEFAULT\&search=virtual reality\&hits $=2442$

Casakin, H. (2012). An empirical assessment of metaphor use in the design studio: analysis, reflection and restructuring of architectural design. International Journal of Technology and Design Education, 22(3), 329-344. https://doi.org/10.1007/s10798-010-9149-x

Ekow, A., \& Vincentia, A. (2013). Sirigu Symbols : A Metaphoric Element for Batik Prints. Arts and Design Studies, 12, 49-58.

Janesick, V. J. (1994). The dance of qualitative research design: Metaphor, methodolatry, and meaning. PsycNET. In Handbook of qualitative research (pp. 209-219). Thousand Oaks: Sage Publications, Inc. Retrieved from https://psycnet.apa.org/record/1994-98625-011

Johnson, N. R. (2006). Metaphor and Design. Studies in Art Education, 33(3), $144-153$. https://doi.org/10.1080/00393541.2006.11650084

Kridalaksana, H. (2008). Kamus Linguistik. Jakarta: Gramedia.

Luxemburg, J. Van, Bal, M., \& Westseijn, W. G. (1989). Pengantar Ilmu Sastra. (Dick Hartoko, Ed.). Jakarta: Gramedia. Retrieved from http://library.um.ac.id/free-contents/index.php/buku/detail/pengantar-ilmusastra-jan-van-luxemburg-mieke-bal-willem-g-westseijn-diindonesiakan-oleh-dick-hartoko-3776.html 


\section{Jurnal Elektronik WACANA ETNIK - Vol 6 No 2 Oktober 2017, (56 - 66) \\ p ISSN 2089-8746, e ISSN 2302-7142}

Marcus, A. (1998). Metaphor design in user interfaces. ACM SIGDOC Asterisk Journal of Computer Documentation, 22(2), 43-57. https://doi.org/10.1145/291391.291397

Noble, J., Biddle, R., \& Tempero, E. (2002). Metaphor and metonymy in object-oriented design patterns. Australian Computer Science Communications, 24(1), 360. Retrieved from https://dl.acm.org/citation.cfm?id=563823

Saffer, D. (2005). The Role of Metaphor in Interaction Design. Citeseer. Carnegie Mellon University.

Schwen, T. M., \& Hara, N. (2003). Community of Practice: A Metaphor for Online Design? The Information Society, 19(3), 257-270. https://doi.org/10.1080/01972240309462

Stubblefield, W. A. (1998). Patterns of Design In Change Metaphors.pdf. In ACM computer human interaction conference. Los Angeles.

Tarigan, H. G. (1995). Pengajaran Semantik. Bandung: Angkasa.

Ullmann, S. (2007). Pengantar Semantik. (Sumarsono, Ed.). Yogyakarta: Pustaka Pelajar. 